\title{
Management of angular cheilitis in children
}

\author{
Fajriani* $^{*}$
}

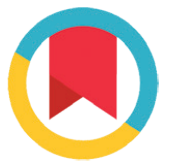

CrossMark

\section{Abstract}

Objective: This paper aims to inform colleagues about management of angular cheilitis in children. Angular cheilitis is a type of oral soft tissue disease that can occur in children and adults, the condition is characterized by cracks and inflammation on both corners of the mouth. Methods: Angular cheilitis or perleche is an inflammation reaction on the corner of the mouth often started from mucocutaneous aberration and continued to skin.
Results: This disease can not cause severe disorder, it quite disturbs one's activity and physical appearance. Mild Angular cheilitis will recover itself over times. However severe conditions can cause pain and bleeding.

Conclusion: Treatment of angular cheilitis is by eliminating the etiology factors. Secondary infection must be remembered
Department of Pediatric, Faculty of Dentistry, Hasanuddin University, Makassar, Indonesia
*Correspondence to: Fajriani, Department of Pediatric, Faculty of Dentistry, Hasanuddin University, Makassar, Indonesia fajrianifkg@gmail.com

Received: 10 0ctober 2016 Revised: 11 0ctober 2016 Accepted: 03 January 2017 Available Online: 01 April 2017

Keywords: Management, Angular cheilitis, Child

Cite this Article: Fajriani. 2017. Management of Angular Cheilitis in children. Journal of Dentomaxillofacial Science 2(1): 1-3. D0l:10.15562/jdmfs. v2i1.461

\section{Introduction}

Angular cheilitis occurs more in children and it is caused by children sensitivity against certain contact agents like toys, foods, sunlight, allergy against medicines, cosmetics and long term antibiotic treatment. Disease attacking the corners of the mouth is often cause pain when patients experience dry mouth or xerostomia. This disease can also be caused by vitamin B complex deficiency, blood iron deficiency, denture sore mouth and other factors such as breathing through mouth, wetting lips with tongue and licking the corner of the mouth with tongue. Angular cheilitis also called perleche or angular cheilitis is a lesion marked with fissures, cracks on corner of lip, reddish, ulceration accompanied by burning sensation, pain and dryness on the corner of the mouth. In severe cases, these cracks can bleed when opening the mouth and cause shallow ulcer or krusta. ${ }^{1-3}$

Angular cheilitis can be a serious problem if it is not handled properly. This disease progression is so fast.There for there should be no delay in treatment if symptoms of angular cheilitis occurred and very clear. Not limited to a certain age, regardless of their sex all can be affected by this disease. Frequently in child aged $4-6$ years. ${ }^{3,4}$

Clinically, angular cheilitis can occur in chronic condition, where the corner of mouth or mouth inflamed because of wound infection. Infection that caused this condition is a type of fungi or bacteria. Affected area usually feels pain and healing period depends on the treatment. All ages can be affected by this disease. The more vulnerable ones are those with a weak immune system, diabetes mellitus and those that flooded their saliva on the corner of their lips. Patients who have undergone head and neck radiation also runs the risk of developing angular cheilitis, also those who have iron deficiency, vitamin B12 deficiency and folic deficiency. ${ }^{2-5}$

\section{Methods}

Angular cheilitis or perleche is an inflammation reaction on the corner of the mouth often started from mucocutaneous aberration and continued to skin. It characterized by reddish lesions that spread in form of fissures, skin appear eroded, ulcer surface plated and accompanied by subjective symptoms such as pain, burning sensation and aches. Perleche term used for angular cheilitis caused by vitamin $B$ complex deficiency, but now has been generalized to all angular cheilitis with various etiologies. ${ }^{5-7}$

Factors that caused angular cheilitis are candidiasis, trauma on oral cavity, nutrition status of children, manifestations of systemic disease and viral infections. The cause of angular cheilitis prominent in children is a nutritional deficiency. Nutritional deficiency is usually caused by inadequate intake of vitamin B complex (riboflavin), iron and folic acid. ${ }^{7,8}$

Clinical Features is characterized by the existence of fissures and erythema on the corners of the mouth, which extended to bottom lip and possibly extended to buccal mucosa. Angular cheilitis has other names, perleche, angular cheilosis and angular stomatitis. Angular cheilitis initial symptom is itchiness on the corner of the mouth and it looks 
corner of the mouth and looks appearance inflamed skin and red spots. At first, it is not dangerous but it will feel pain on the corner of the mouth and bleed easily that is caused by the movement of the mouth such as laughing or talking. The inflammation severity is characterized by cracks on corner of the mouth and some bleeding when the patient's mouth opened in angular cheilitis associated with nutritional deficiencies can be seen the depletion of tongue papillae (depapillated tongue) due to iron deficiency. The tongue is red and shiny (depapillated glossy red tongue) in patients. ${ }^{8,9}$

Management and treatment to prevent the growth of candida albicans, one of the causes of angular cheilitis on the corner of the mouth, is to re-balance the oral environment. The most important thing is to maintain a healthy body so that the immune system is maintained and not susceptible to disease and to eat foods that are nutritionally balanced and needed by the body. Besides that we also undertake maintenance of oral hygiene by brushing your teeth. By brushing teeth, oral hygiene will be maintained in addition to avoiding the formation of carries in the teeth, tooth and gum disease. . $^{8-10}$

\section{Results}

Treatment of angular cheilitis in children does not different to adult. The treatment depends on its etiology. If the specific etiology remains unfound, these lesions can be difficult to cure and it can last up to several years. It must be remembered that infection is secondary etiology. If the main cause is not treated, the treatment of infection will not produce a permanent result. For example, breathing habit through mouth in child must be stopped, same like the other habits. If it is caused by systemic disease, local treatment will not be successful if not accompanied by systemic treatment. ${ }^{10,11}$

Angular cheilitis caused by vitamin B deficiency should be treated by providing vitamin $B$ complex supplement or multivitamin that contain vitamin B. However, deficiency of one type of vitamin is usually followed by nutritional deficiency, hence in the treatment, multivitamin administration is more effective than vitamin $B$ complex alone. Reported treatment of disease caused by vitamin B12 deficiency with vitamin therapy can be healed in 3 weeks. Antimicrobial administration on patients with angular cheilitis caused by nutritional deficiency is only shortened the healing time. Because most of the infection that occur can heal itself without antimicrobials, body's defense system should be maintained or increased by administering vitamin supplements or multivitamins. ${ }^{11,12}$

\section{Discussion}

Angular cheilitis occurs in children frequently because of lack of nutrition. Bacterial infection and mechanical factor often occur in children with bad habits such as licking the corner of the lip and sucking finger. These will accumulate the saliva on the corner of the mouth and unwittingly provide perfect environment for infectious agents in causing angular cheilitis. Trauma on mouth cavity can be caused by mechanic, chemical and thermal. Mechanical trauma can be caused by irritation from sharp cups, orthodontic instruments and biting lips or cheeks. Diagnoses of this type are usually not difficult depending on the position, shape and size of the ulceration which should correspond to the suspected cause. Ulceration usually begins to heal within 10 days. If healing does not occur then the other causes of ulceration should be suspected. . $^{3,47}$

Nutritional Status of Children in which the main cause of angular cheilitis in children is a nutritional deficiency caused by lack of vitamin B complex (riboflavin), iron and folic acid. In causing angular cheilitis, each of the etiologic factors, especially nutritional deficiency is correlated with environmental conditions. In students the most influential ones are environmental conditions in both family and school. Referred environmental conditions can be family's socioeconomic level, indigenous influences in the family, habits or eating patterns in children and knowledge about nutritions. ${ }^{4,8}$

Various manifestations of systemic disease in which a patient suffering from a disease that affects the entire body and show signs and specific oral symptoms such as haematological disorders: anemia due to iron deficiency, endocrine disorders: diabetes mellitus, viral infections: human immunodeficiency virus, advanced malignant disease, leukemia, hematological disorder in patients suffer from anemia. Iron deficiency has a tendency for some diseases of oral mucosa includes: aphthous ulceration, angular cheilitis, pain and cracks on corners of the mouth caused by the fungus candida albicans and by staphylococcus aureus bacteria. Mucosal atrophy is mucosa that appears reddened and smooth. It is important to think of iron deficiency, anemia in patients with aphthous ulceration and angular cheilitis. If iron deficiency anemia is not detected, other causes must be investigated. ${ }^{9,11}$

Virus infection is not like bacteria that consist of a single cell and is able to grow independently. Virus consists of small nuclear fragment surrounded by protein coat. It can not divide or replicate itself and to survive it must gain access to live inside cells. Upon entering host cell, it usedits process of synthetic in host cell to reproduce and in the process, often damaging the host cell. In other cases, 
the host will destroy virally infected cells in order to eliminate the virus. This is the cellular destruction that is responsible for many of the clinical features of viral infections that affect the oral cavity. The time needed for the virus to infect the host, to replicate and to damage cells and thus clinical symptoms might occur on days 3-21 and is known as the incubation period. Most viruses with severe infections between 10 and 14 days, after the hosts had an effective immune response and the infection resolved. Other less virulent infection may last only a few days. Viral infection generally affects younger age groups and viral infections that occur in older age groups possibly underlying immunosuppression. ${ }^{5,10}$

\section{Conclusion}

Angular cheilitis appeals diagnosed with herpes lesions labialis, ulcers, impetigo, and secondary syphilis lesions. Treatment of angular cheilitis is by eliminating the etiology factors. Secondary infection must be remembered. If the primary cause is not corrected, the treatment of the infection will not produce a permanent cure.

\section{Conflict of Interest}

The authors report no conflict of interest.

\section{References}

1. Muray JJ, Nunn J. H.Steele J. The prevention of oral disease 4th ed. New york: oxford University Press; 2008.
2. Boedihardjo. Pemeliharaan kesehatan gigi keluarga. Surabaya: Airlangga University Press; 1985.

3. Gayford JJ, Haskel R. Penyakit mulut (clinical oral medicine). Jakarta: EGC; 1990.

4. DowlW.Effect of angular cheilitis on children and teenagers.[internet].Available at URL: http://www.EzineArticles/ childandac.html. Accesses 25December 2010

5. Lubis S. Hubungan status gizi dengan keilitisangularis pada anak umur 6-12 tahun di enam panti asuhan di Kota Madya Medan. Dentika J Dent 2006;11: 180-181.

6. Tydesley WR. A colour atlas of orofacial disease (Atlas berwarna penyakit orofasial) 3th ed. Jakarta: Widya Medika; 1991.

7. Faiz R. Angular cheilitis overview and symptoms of angularcheilitis.[Internet]Available at: http://www.articlesbase. $\mathrm{com} / \mathrm{skin}$-care-articles/angular-cheilitis-overview-andsypmtoms-of-angular-cheilitis-285629.html >.Accessed 28 December 2010

8. Deritana N, Kombong A. Gizi untuk pertumbuhan dan perkembangan. Jayawijaya: J WATCH; 2007. p. 5-18

9. Rippon JW. Medical mycology. 3th ed. Philadelphia : WB SaundersCo; 1988

10. Hari S. Angular cheilitis: Review of etiology and clinical management .K.D.J.[Internet] Available at: http://www. trivandrum.co.uk. Accessed 27 December 2010.

11. Langlais RP, Craig SM. Atlas Berwarna : Kelainan Rongga Mulut yang Lazim. 1st ed. Jakarta: Hipokrates; 2003. p. 34.

12. Morison MJ. Manajemen luka. Jakarta: EGC; 2003. p. 1-21.

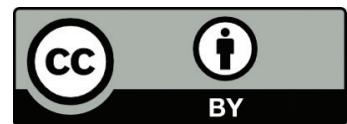

This work is licensed under a Creative Commons Attribution 